\title{
Genetic analysis of Bromus tectorum (Poaceae) in the Mediterranean region: biogeographical pattern of native populations
}

\author{
Lauren J. Kelly ${ }^{1} \cdot$ Richard N. Mack ${ }^{1} \cdot$ Stephen J. Novak $\mathbb{D}^{2}$
}

Received: 30 January 2020 / Revised: 27 July 2020 / Accepted: 1 August 2020 / Published online: 19 August 2020

(c) The Author(s), under exclusive licence to The Genetics Society 2020

\begin{abstract}
Genetic diversity within and among 42 native populations of Bromus tectorum (cheatgrass) was characterized within two regions, the eastern Mediterranean and the western Mediterranean. Two hypotheses were tested for the genetic diversity of these populations: (1) populations from the eastern Mediterranean are more genetically diverse compared with populations to the west, a potential consequence of the species' westward dispersal with the spread of agriculture, and (2) populations across the Mediterranean contain comparable genetic diversity but display high genetic differentiation, a potential consequence of both regions having served as refugia during glacial advances in the late Quaternary Period. Populations in the eastern Mediterranean possess 16 polymorphic loci and 37 multilocus genotypes. In contrast, populations from the western Mediterranean include a subset of these polymorphic loci (9) and fewer multilocus genotypes (19), consistent with the dispersal of B. tectorum with the east-west Holocene spread of agriculture. Among the 19 multilocus genotypes identified in populations from the western Mediterranean, 13 are undetected among eastern Mediterranean populations. Average genetic diversity within populations from the eastern Mediterranean is nonetheless comparable to the genetic diversity in populations from the Iberian Peninsula, whereas diversity is the lowest in the populations from southern France. Our results suggest a prominent role for agriculture in the grass's western spread, although glacial history and environmental heterogeneity also could have influenced the grass's genetic diversity. The exceptionally high level of self-pollination $(>99 \%)$ in B. tectorum has contributed to preserving the genetic signature associated with the species' biogeographical history across the Mediterranean region.
\end{abstract}

\section{Introduction}

The Mediterranean region is a natural laboratory for investigating the confluences of ecology, evolutionary biology, and cultural history, as they relate to the geographic origins of many plant species introduced into North America and elsewhere (Esler et al. 2018). The lands that ring the Mediterranean Basin are global biodiversity

Associate editor: Thomas Meagher

Supplementary information The online version of this article (https:// doi.org/10.1038/s41437-020-00354-0) contains supplementary material, which is available to authorized users.

Stephen J. Novak

snovak@boisestate.edu

1 School of Biological Sciences, Washington State University, Pullman, WA 99164, USA

2 Department of Biological Sciences, Boise State University, 1910 University Dr., Boise, ID 83725-1515, USA hotspots (Myers et al. 2000; Blondel and Medail 2009) and include more than 24,000 vascular plant species (Comes 2004; Nieto Feliner 2014); $26 \%$ of these species are regional endemics (Greuter 1991). In addition, Medail and Quezel (1997) identified ten smaller biodiversity hotspots within the Mediterranean region, including part of the Middle East (Israel, Lebanon, and Syria), Turkey (southern Anatolia), southern and central Greece, and southern Spain.

The biodiversity and biogeography of Mediterranean and European biota have been influenced by Pleistocene glaciation that created refugia in the Iberian, Italian, and Balkan peninsulas (Taberlet et al. 1998; Hewitt 2000, 2011). Medail and Diadema (2009) reviewed regional intraspecific phylogeographical studies of 82 plant species and identified 52 putative glacial refugia within the Mediterranean region. Collectively, these biodiversity hotspots and glacial refugia have shaped the areal extent and genetic diversity of many species. Human activity has also been an important influence on current distributions and population genetics for many species: humans have altered the region's vegetation as early as 10,000-year BCE (Thompson 2005). The Fertile Crescent 
(Jordan, Iran, Iraq, Israel, Syria, and Turkey) is an origin for agriculture's spread into Europe (Brown et al. 2009) by Neolithic farmers along two main pathways: (1) western movement by sea to Greece and Italy, followed by colonization of southern France and the Iberian Peninsula, and (2) northwestern movement into southeastern and then northern Europe (Balfourier et al. 1998). By 7000-year BCE, Neolithic farming enclaves were established along the coasts of the Balkan, Italian, and Iberian Peninsulas (Zeder 2008).

Many weedy species (e.g., Avena fatua, Lolium perenne, and L. rigidum) likely spread as seed contaminants in conjunction with agriculture; subsequent founder events reduced genetic variation from east to west (Kahler et al. 1980; Erskine et al. 1994; Balfourier et al. 1998). The geographic distribution of Bromus tectorum (cheatgrass, downy brome), a predominantly cleistogamous (self-pollinating) annual $(2 n=14)$, makes it an ideal candidate for examining the relative influence of anthropogenic activity, environmental heterogeneity, and Holocene climate on its genetic diversity (Novak and Mack 1993). B. tectorum is common but usually not abundant throughout most of its putative native range, which includes much of Europe south of the Baltic Sea (Pierson and Mack 1990; Mack 2011), as well as the Middle East and Asia Minor, northwestern coastal North Africa, and much of Chinese central Asia (https://www.gbif.org/species/2703746). In the eastern Mediterranean region, $B$. tectorum occurs frequently in arid, disturbed sites, such as walls, rooftops, and along pathways (Post and Dinsmore 1933; Zohary and Feinbrun-Dothan 1966). On the Iberian Peninsula, B. tectorum occurs in arable sandy soils as well as on walls and rooftops (R.N. Mack, pers. observ.); similarly, in southern France, the grass occurs on disturbed sites, such as pastures and roadsides (S.J. Novak, pers. observ.). In much of the native range, other bromes co-occur (e.g., B. sterilis, B. rubens, and $B$. rigidus) (Willkomm and Lange 1870; Post and Dinsmore 1933; Zohary and Feinbrun-Dothan 1966; S.J. Novak, pers. observ.). The grass has also been transported worldwide over the past 200 years and has become a major invader in arid (but not desert) regions of North America, especially the Intermountain West of the United States (Mack 2011 and refs. therein).

In a paper published previously in Heredity (Novak and Mack 1993), we examined the allozyme diversity of 51 native populations of B. tectorum from Europe and southwest Asia. Greater genetic diversity, on average, was reported within southwest Asian populations than within European populations. In addition, these 51 native populations possess greater allelic richness and more polymorphic loci than populations in the introduced North American range (see Novak and Mack 2016). In this study, we report the allozyme diversity of additional native population of $B$. tectorum. These 42 populations were sampled from the eastern Mediterranean and the western Mediterranean, and the results presented here are used to assess the processes that have shaped the genetic diversity of the grass in these two regions.

We sought to answer three main questions: (1) does the genetic diversity and structure of these populations provide evidence of anthropogenic activity in the spread of $B$. tectorum, particularly with the westward spread of agriculture from the Fertile Crescent (Pinhasi et al. 2005)? Under this scenario, populations from the western Mediterranean region would likely be less genetically diverse and contain only a subset of the genotypes found in populations from the eastern Mediterranean, or (2) is the genetic diversity and structure of all these populations consistent with the pattern observed for populations sampled from putative glacial refugia? Under this scenario, populations from the eastern and western Mediterranean would have comparable levels of genetic diversity, but be genetically differentiated from each other because they were genetically isolated during the late Quaternary Period, and (3) how does the level of genetic diversity within eastern and western Mediterranean populations of this grass compare to the genetic diversity reported previously for 51 native populations of the species, especially populations from central and northern Europe?

\section{Materials and methods}

\section{Collection protocol}

Collection of samples involved the removal of mature caryopses (hereafter referred to as seeds) from individuals in each of 42 populations in the Mediterranean region (Supplementary Information Table 1). Samples were obtained from three populations each in Jordan and Syria, 11 populations in Israel, 14 populations in France, seven populations in Spain, and four populations in Portugal. Collection locations were selected to enhance the resolution of the genetic diversity within populations and the genetic structure within and among populations across this portion of the native range. Collections were made in disturbed sites, e.g., pastures and agricultural fields, roadsides, and archeological ruins (see Supplementary Information Table 1). Each population was sampled from an area of at least $500 \mathrm{~m}^{2}$, and we collected seeds (mature panicles) from 25 to 35 plants from each population (with two exceptions: Shinshar, SY, $N=12$; Sisteron, FR, $N=20$ ). To minimize inadvertently collecting full siblings in this highly self-pollinating plant species (Novak and Mack 2016), individuals were collected 1-2 $\mathrm{m}$ apart. In low-density populations, the entire population was sampled. To account for seed dormancy (Allen and Meyer 2002), seeds were stored at room temperature in paper envelopes for at least 3 months before being germinated for analysis. 


\section{Allozyme analysis}

Allozymes are single-locus, codominant molecular markers; consequently, the genotype of individuals (i.e., homozygous vs. heterozygous) can be inferred from enzyme-banding patterns at each scored locus. Although allozymes underestimate genetic diversity compared with other markers (Rowe et al. 2017), their use here allows these results to be compared directly with the findings of our previous analyses of 51 native populations of B. tectorum (Novak and Mack 1993) and 318 invasive populations in North America (Novak and Mack 2016). In addition, our extensive use of allozymes has optimized the procedures for this species. Finally, allozymes are a relatively rapid method for gathering population genetic data; the genotypes of $\sim 30$ individuals at each of 25 allozyme loci could be characterized per day.

In preparation for allozyme analysis, seeds were germinated on moist filter paper and allowed to grow for 7-10 days. Harvesting occurred when seedlings were between 2- and 8-cm tall. Allozyme analysis was performed using the methods of Soltis et al. (1983) as modified by Novak et al. (1991) and Schachner et al. (2008). The 15 enzymes assayed in this study were coded by 25 putative loci (Supplementary Information Table 2). As reported repeatedly (e.g., Valliant et al. 2007; Huttanus et al. 2011; Pawlak et al. 2015), the genotype found most frequently in the native and introduced range is referred to as the most common genotype (MCG) (Supplementary Information Table 2). Allele nomenclature for B. tectorum initially followed Novak and Mack (1993) but has been updated based on the results of the new analyses reported here (see below).

\section{Data analysis}

Alleles for every individual in a population were recorded at each of the 25 loci and analyzed using BIOSYS-1 (Swofford and Selander 1989), following the methods of Novak et al. (1991), Huttanus et al. (2011), and Pawlak et al. (2015). To answer the main questions of this study, 42 populations of $B$. tectorum we analyzed were grouped into two geographic regions, the eastern Mediterranean (populations from Israel, Jordan, and Syria) and the western Mediterranean (populations from Spain, Portugal, and southern France). In addition, the populations from Spain and Portugal were further grouped into the Iberian Peninsula region. Genetic diversity was described using the following parameters: the number of alleles per locus $(A)$, the number of polymorphic loci $(P)$, the percentage of polymorphic loci $(\% \mathrm{P}$; a locus is polymorphic if the most common allele $\leq 99 \%$ ), expected mean heterozygosity $\left(H_{\text {exp }}\right)$, the mean observed heterozygosity $\left(\mathrm{H}_{\mathrm{obs}}\right)$, and the number of homozygous multilocus genotypes (\#MLGs).
Expected mean heterozygosity was computed using Nei's (1978) unbiased estimate method. Mean observed heterozygosity $\left(H_{\text {obs }}\right)$ was obtained through the direct count method, and the statistical significance of deviations from random mating was analyzed using a Chi-square test. Allele combinations were identified and evaluated by determining the number and frequency of distinct homozygous MLGs for each population.

Allelic frequencies, Wright's fixation index $(F=1-$ $\left.H_{\text {obs }} / H_{\text {exp }}\right)$, and Wright's $F$ statistics $\left(F_{\mathrm{IT}}\right.$ and $\left.F_{\mathrm{ST}}\right)$ were computed for all polymorphic loci (Wright 1965, 1978) using BIOSYS-1 (Swofford and Selander 1989). Variance components in Wright's $F$ statistics (1978) were employed to calculate Nei's gene (allelic) diversity statistics (Nei 1973, 1977); the diversity partitioned within populations $\left(H_{\mathrm{S}}\right)$ and diversity partitioned among populations $\left(D_{\mathrm{ST}}\right)$ were summed to obtain the value of the total gene diversity $\left(H_{\mathrm{T}}\right)$. Proportion of the total gene diversity partitioned among populations $\left(G_{\mathrm{ST}}\right)$ was calculated as $G_{\mathrm{ST}}=D_{\mathrm{ST}} / H_{\mathrm{T}}$. Means of the diversity statistics were compared to the means of previously analyzed populations in the native range of B. tectorum (Novak and Mack 1993; Novak and Mack 2016).

Nei's (1978) unbiased genetic-identity coefficients (I) were computed to evaluate genetic similarity within and among populations from the eastern and western Mediterranean and all pairwise comparisons $(I=1.0$ denotes genetically identical populations, and $I=0.0$ indicates complete genetic differentiation among populations). Phenograms for 17 populations from the eastern Mediterranean region, 25 populations from the western Mediterranean region, and all 42 populations from the study area were constructed using the unweighted pair-group method with arithmetic averaging (UPGMA) algorithm in BIOSYS-1, based on the values of genetic identity $(I)$ (Swofford and Selander 1989). The UPGMA phenograms were used to examine the genetic relationships among all 42 populations, as well as among the populations from the eastern and western Mediterranean regions.

\section{Results}

\section{Allozyme diversity}

For 42 populations from the Mediterranean region, a total of 1342 individuals were analyzed, including 545 individuals from the eastern Mediterranean Region and 797 individuals from the western Mediterranean region ( 32 individuals per population; Supplementary Information Table 3 and Table 1). Across the 25 scored loci, 16 loci $(64 \%)$ are polymorphic: Adh-1, G6pdh-2, Got-1, Got-2, Got-3, Got-4, Idh-1, Lap-1, Mdh-1, Mdh-2, Mdh-3, Me-1, Pgi-2, Pgm-1, 
Table 1 Genetic diversity parameters for 42 populations of Bromus tectorum from the Mediterranean region.

\begin{tabular}{|c|c|c|c|c|c|c|c|c|}
\hline Region & Population & $N$ & $A$ & $P$ & $\% P$ & $H_{\exp }$ & $H_{\mathrm{obs}}$ & \#MLGs \\
\hline \multirow[t]{17}{*}{ Eastern Mediterranean } & 1. Jerusalem 1, IL & 34 & 1.16 & 4 & 16.0 & 0.009 & 0.000 & 3 \\
\hline & 2. Pisgat, IL & 34 & 1.12 & 3 & 12.0 & 0.018 & 0.000 & 3 \\
\hline & 3. Jerusalem 2, IL & 35 & 1.28 & 7 & 28.0 & 0.050 & 0.000 & 6 \\
\hline & 4. Golan, IL & 35 & 1.08 & 2 & 8.0 & 0.029 & 0.000 & 4 \\
\hline & 5. MS foothills, IL & 35 & 1.08 & 2 & 8.0 & 0.022 & 0.000 & 3 \\
\hline & 6. MS summit, IL & 34 & 1.16 & 4 & 16.0 & 0.047 & 0.001 & 11 \\
\hline & 7. Shaal, IL & 31 & 1.12 & 3 & 12.0 & 0.050 & 0.000 & 7 \\
\hline & 8. Mas'ada, IL & 33 & 1.12 & 3 & 12.0 & 0.029 & 0.000 & 5 \\
\hline & 9. MH foothills, IL & 34 & 1.08 & 2 & 8.0 & 0.037 & 0.000 & 6 \\
\hline & 10. MH entrance, IL & 35 & 1.16 & 4 & 16.0 & 0.041 & 0.000 & 6 \\
\hline & 11. MH station, IL & 35 & 1.12 & 3 & 12.0 & 0.017 & 0.000 & 5 \\
\hline & 12. Shobak Castle, JO & 29 & 1.04 & 1 & 4.0 & 0.005 & 0.000 & 2 \\
\hline & 13. Petra Trail, JO & 27 & 1.16 & 4 & 16.0 & 0.036 & 0.000 & 4 \\
\hline & 14. Petra Hotel, JO & 34 & 1.08 & 2 & 8.0 & 0.013 & 0.000 & 3 \\
\hline & 15. Ma'loula, SY & 34 & 1.16 & 4 & 16.0 & 0.055 & 0.000 & 5 \\
\hline & 16. Seydnaya, SY & 34 & 1.04 & 1 & 4.0 & 0.002 & 0.000 & 2 \\
\hline & 17. Shinshar, SY & 12 & 1.00 & 0 & 0.0 & 0.000 & 0.000 & 1 \\
\hline \multirow[t]{26}{*}{ Western Mediterranean } & 18. Retortillo, ES & 31 & 1.12 & 3 & 12.0 & 0.032 & 0.000 & 4 \\
\hline & 19. San Clemente, ES & 30 & 1.04 & 1 & 4.0 & 0.011 & 0.000 & 2 \\
\hline & 20. Canamares, ES & 34 & 1.08 & 2 & 8.0 & 0.016 & 0.001 & 4 \\
\hline & 21. Robledillo, ES & 31 & 1.12 & 3 & 12.0 & 0.034 & 0.001 & 5 \\
\hline & 22. Alarba, ES & 29 & 1.08 & 2 & 8.0 & 0.019 & 0.000 & 2 \\
\hline & 23. Pedraza, ES & 29 & 1.12 & 3 & 12.0 & 0.026 & 0.000 & 4 \\
\hline & 24. Guadalupe, ES & 25 & 1.04 & 1 & 4.0 & 0.013 & 0.000 & 2 \\
\hline & 25. Minhocal, PT & 35 & 1.16 & 4 & 16.0 & 0.049 & 0.000 & 8 \\
\hline & 26. Arronches, PT & 29 & 1.08 & 2 & 8.0 & 0.017 & 0.000 & 3 \\
\hline & 27. TDM, PT & 33 & 1.16 & 4 & 16.0 & 0.044 & 0.001 & 7 \\
\hline & 28. Castelo B, PT & 31 & 1.08 & 2 & 8.0 & 0.023 & 0.000 & 3 \\
\hline & 29. Sisteron, FR & 20 & 1.00 & 0 & 0.0 & 0.000 & 0.000 & 1 \\
\hline & 30. Monte-Louis, FR & 35 & 1.04 & 1 & 4.0 & 0.016 & 0.000 & 2 \\
\hline & 31. Sournia, FR & 33 & 1.00 & 0 & 0.0 & 0.000 & 0.000 & 1 \\
\hline & 32. Sederon, FR & 34 & 1.00 & 0 & 0.0 & 0.000 & 0.000 & 1 \\
\hline & 33. Tarascon, FR & 30 & 1.00 & 0 & 0.0 & 0.000 & 0.000 & 1 \\
\hline & 34. Montaron, FR & 34 & 1.00 & 0 & 0.0 & 0.000 & 0.000 & 1 \\
\hline & 35. L'Esperou, FR & 35 & 1.00 & 0 & 0.0 & 0.000 & 0.000 & 1 \\
\hline & 36. Fontfroide, FR & 35 & 1.00 & 0 & 0.0 & 0.000 & 0.000 & 1 \\
\hline & 37. Bueges, FR & 35 & 1.04 & 1 & 4.0 & 0.002 & 0.000 & 2 \\
\hline & 38. St. Laurent, FR & 35 & 1.04 & 1 & 4.0 & 0.017 & 0.000 & 2 \\
\hline & 39. Cabrespine, FR & 35 & 1.04 & 1 & 4.0 & 0.019 & 0.000 & 2 \\
\hline & 40. Albieres, FR & 35 & 1.00 & 0 & 0.0 & 0.000 & 0.000 & 1 \\
\hline & 41. Col Homme, FR & 29 & 1.00 & 0 & 0.0 & 0.000 & 0.000 & 1 \\
\hline & 42. Col Vence, FR & 35 & 1.00 & 0 & 0.0 & 0.000 & 0.000 & 1 \\
\hline & Mean & 32 & 1.08 & 1.9 & 7.62 & 0.00001 & 0.019 & 3.29 \\
\hline
\end{tabular}

Population numbers and acronyms are as given in Supplementary Information Table 1. Also provided are the number of individuals analyzed for each population $(N)$, the mean number of alleles per locus $(A)$, the number of polymorphic loci $(P)$, the percent polymorphic loci $(\% P)$, the expected mean heterozygosity per locus $\left(H_{\text {exp }}\right)$, the mean observed heterozygosity per locus $\left(H_{\mathrm{obs}}\right)$, and the number of multilocus genotypes (\#MLGs) for each population. Heterozygous individuals were detected in four populations, MS summit, IL, Canamares, ES, Robledillo, ES, and TDM, PT. 
Pgm-2, and $S k d h-1$, and 49 alleles were detected (1.96 alleles per locus) (Supplementary Information Tables 2 and $3)$. Thirty-one of 42 populations (73.8\%) contained polymorphic loci: 21 of these 31 populations are polymorphic at two or more loci (Supplementary Information Table 3).

Our allozyme analysis detected 11 alleles not reported previously in populations of $B$. tectorum. Consequently, we updated the allelic nomenclature for the species (see Supplementary Information Table 2). These alleles (and the location of plants with these alleles) are G6pdh-2b (Mt. Shifon summit, Israel), Got-1a and Got-2a (Malou'la, Syria), Got-3a (Arronches, Portugal), Got-4d (seven Israeli populations), a null allele designated Got- $4 f$ (Petra Hotel, Jordan), $M d h-1 a$ (two populations from Jerusalem), Mdh- $1 c$ (Monte-Louis, France), Pgm- $1 c$ and Pgm-2c (Mt. Hermon, Israel), and Skdh-1c (Minhocal, Portugal) (Supplementary Information Tables 2 and 3). Three of these alleles (Got-3a, $M d h-1 c$, and $S k d h-1 c$ ) occur in populations from the western Mediterranean region only. Pgi-2 is the most polymorphic locus, varying from the MCG in 25 populations (Supplementary Information Table 3). Eight populations are polymorphic for Me-1. Got-3 and Got-4 are highly polymorphic, varying in nine and eight populations, respectively. The other 12 polymorphic loci occur in one to six populations (Supplementary Information Table 3).

Populations from the eastern Mediterranean contain 16 polymorphic loci and 46 alleles; populations from the western Mediterranean contain nine of these 16 polymorphic loci (Got-3, Idh-1, Lap-1, Mdh-1, Me-1, Pgi-1, Pgm-1, Pgm-2, and Skdh-1) and 35 alleles (Supplementary Information Table 3).

\section{Multilocus genotypes}

Fifty MLGs were detected across all 42 populations from the Mediterranean region (Figs. 1, 2, and Table 2); six of these genotypes are shared among populations from the eastern and western Mediterranean regions. Thirty-one MLGs are found exclusively in populations from the eastern Mediterranean region, whereas 13 genotypes detected in populations from the western Mediterranean are specific to that region (Table 2).

Across the Mediterranean region, the MCG occurs in 35 of $42(83.3 \%)$ populations (Figs. 1 and 2). All 17 populations from the eastern Mediterranean region have the MCG in varying frequencies compared with 18 of 25 (72.0\%) populations from the western Mediterranean region. The Pgi-2b MLG occurs in 18 of 42 (42.9\%) populations across the study area: six populations from the eastern Mediterranean region and 12 populations from the western Mediterranean Region. Eight populations from southern France and one Syrian population are fixed for the MCG, whereas two southern France populations are fixed for the Pgi-2b genotype. All other populations analyzed in this study have two or more MLGs.

In the eastern Mediterranean region, the Mt. Shifon summit population has 11 MLGs (Table 1 and Fig. 1). This population contains the most genotypes among the 42 populations analyzed here. The population collected at Shaal, Israel has seven MLGs; three other populations from Israel have six genotypes (Jerusalem 2, Mt. Hermon entrance, and Mt. Hermon foothills). In the western Mediterranean region, the population from Minhocal, Portugal has the largest number of MLGs (8) and the population from Torre de Moncorvo, Portugal has seven genotypes (Table 1 and Fig. 2). The population from Retortillo, Spain has five MLGs, the largest number of genotypes found among the seven Spanish populations we analyzed. No population from southern France has more than two MLGs. On average, populations in the eastern Mediterranean have a larger number of MLGs per population (4.35), compared with populations from the western Mediterranean (2.4) $(F=4.15, P<0.02)$ (Fig. 3).

Of the 50 MLGs reported here (including the MCG), 40 genotypes are unique to this study (i.e., previously undetected in the grass's native and invasive populations) (Table 2). Three of 37 MLGs detected among eastern Mediterranean populations (MCG, Got-4c, and Pgm-lal $P g m-2 a$ ) had previously been reported in populations from central and northern Europe (Novak and Mack 1993). In addition, few MLGs detected among these 42 Mediterranean populations have been detected among 318 North American populations analyzed previously (Novak and Mack 2016): six of 37 genotypes detected in populations from the eastern Mediterranean and three of 19 genotypes detected in populations from the western Mediterranean region (Table 2).

\section{Genetic diversity within populations}

Among the 42 populations we analyzed, the mean number of alleles per locus $(A)$ is 1.08 , the mean number of polymorphic loci per population $(P)$ is 1.90 , the mean value for the percentage of polymorphic loci $(\% P)$ is 7.62 , the value for expected mean heterozygosity $\left(H_{\exp }\right)$ is 0.019 , and the average number of MLGs per population is 3.29 (Table 1). The highest level of genetic diversity occurs in the Jerusalem 2 (Israel) population $(A=1.28, P=7, \% P=28.00$, $\left.H_{\text {exp }}=0.05, \mathrm{MLG}=6\right)($ Table 1$)$. In the western Mediterranean region, two Portuguese populations (Minhocal and Torre de Moncorvo) have the highest number of alleles per locus (1.16), polymorphic loci (4), percentage of polymorphic loci $(16.0 \%)$, expected mean heterozygosity ( 0.049 and 0.044, respectively), and number of MLGs (8 and 7, respectively). One Syrian population lacks any allozyme diversity, as do 10 of 14 populations from southern France; 


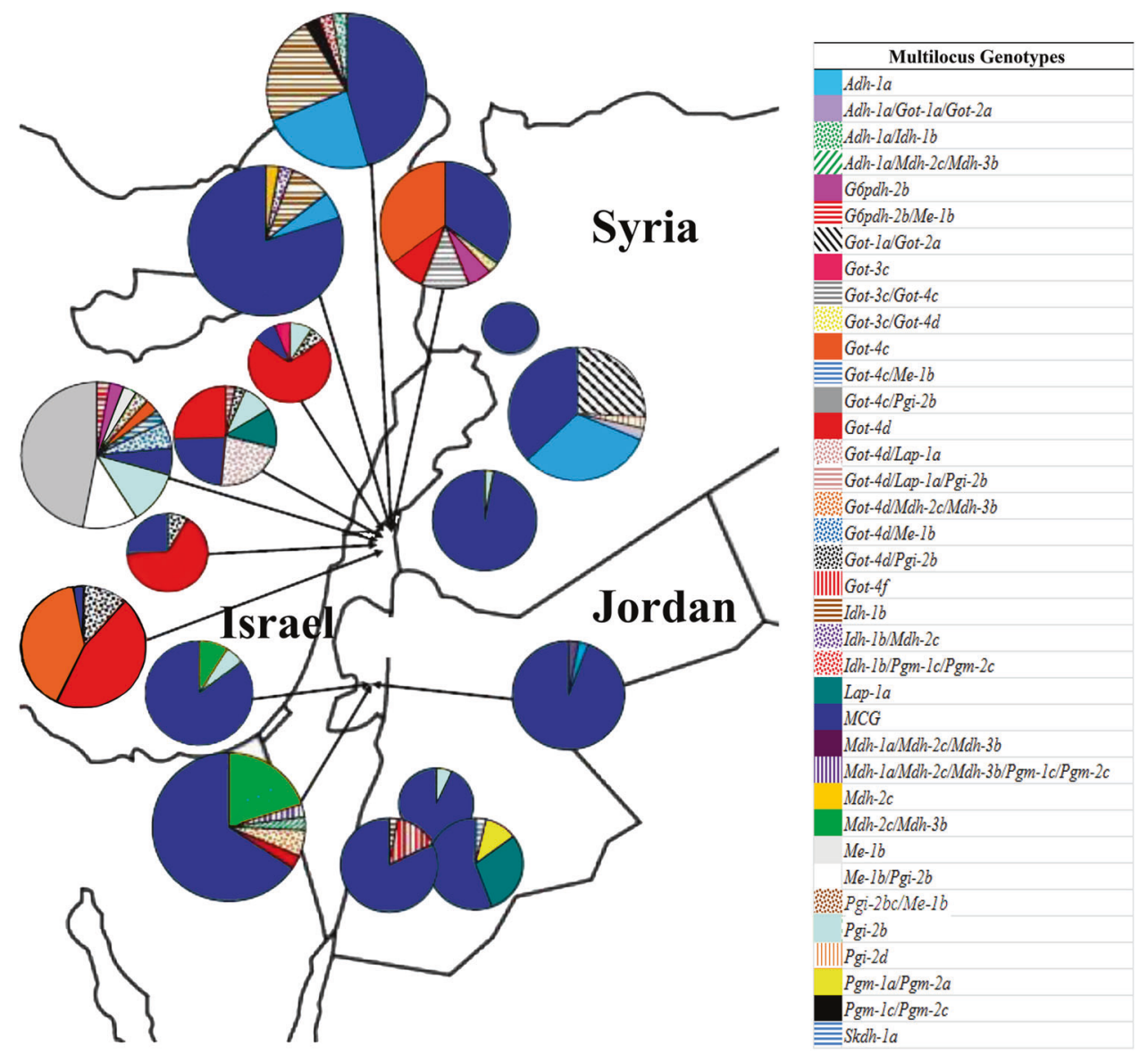

Fig. 1 Multilocus genotypes for 17 populations of Bromus tectorum from the eastern Mediterranean region. Pie diagrams illustrate the proportion of each multilocus genotype in each population. Larger pie diagrams are provided to enhance legibility and do not indicate any other population parameter (e.g., sample size).

the other four southern France populations are polymorphic at only a single locus (Table 1).

The Israeli and Portuguese populations have the highest values for alleles per locus, percentage polymorphic loci, and expected mean heterozygosity, compared with the other populations we analyzed here (Tables 1 and 3). On average, populations from the eastern Mediterranean region have a higher genetic diversity $(A=1.12, P=2.88$, $\% P=11.53, H_{\exp }=0.027$, MLGs $\left.=4.47\right)$ compared with populations from the western Mediterranean region $(A=$ $1.05, P=1.24, \% P=4.96, H_{\exp }=0.014$, MLGs $\left.=2.48\right)$ (Table 3). However, the overall level of genetic diversity in the populations from the eastern Mediterranean region is equivalent to the level in populations from the Iberian Peninsula (Table 3).

Only four of the 1342 individuals we examined were heterozygous: single plants from Mt. Shifon summit, Israel, Torre de Moncorvo, Portugal, Cañamares, Spain, and Robledillo, Spain. These four individuals were all $P g i-2 b c$ heterozygotes. Thus, the value for mean observed heterozygosity in these four populations is 0.001 , and the mean value for all 42 populations is 0.00001 (Table 1). Deviation from random mating is significant for all polymorphic loci across 31 populations exhibiting genetic diversity $(P<$ 0.001 , data not shown). Values of $F_{\mathrm{IT}}$, a measure of the deviation from random mating across populations for each locus, and $F_{\mathrm{IS}}$, the deviation from random mating within a population for each locus, are 1.0 for all loci, except Pgi-2 $\left(F_{\mathrm{IT}}=0.98\right.$ and $\left.F_{\mathrm{IS}}=0.99\right)$ (Table 4). These data indicate significant deviations from Hardy-Weinberg equilibrium due to a deficit of heterozygous individuals.

\section{Genetic differentiation}

The mean value for the total gene (allelic) diversity $\left(H_{\mathrm{T}}\right)$, across the 16 polymorphic loci, is 0.069 (Table 4). Total gene diversity is partitioned into the within-population component $\left(H_{\mathrm{S}}=0.029\right)$ and the among-population component $\left(D_{\mathrm{ST}}=0.040\right)$. The mean value of $G_{\mathrm{ST}}=0.279$ indicates that $28 \%$ of the total gene diversity is partitioned among populations, whereas the balance $(72 \%)$ is partitioned within populations (Table 4). All polymorphic loci have $\mathrm{H}_{\mathrm{T}}$ values $<0.100$, except Pgi-2 $\left(H_{\mathrm{T}}=0.436\right), M e-1$ $\left(H_{\mathrm{T}}=0.238\right)$, and Got $-4\left(H_{\mathrm{T}}=0.161\right)$. These three are the 


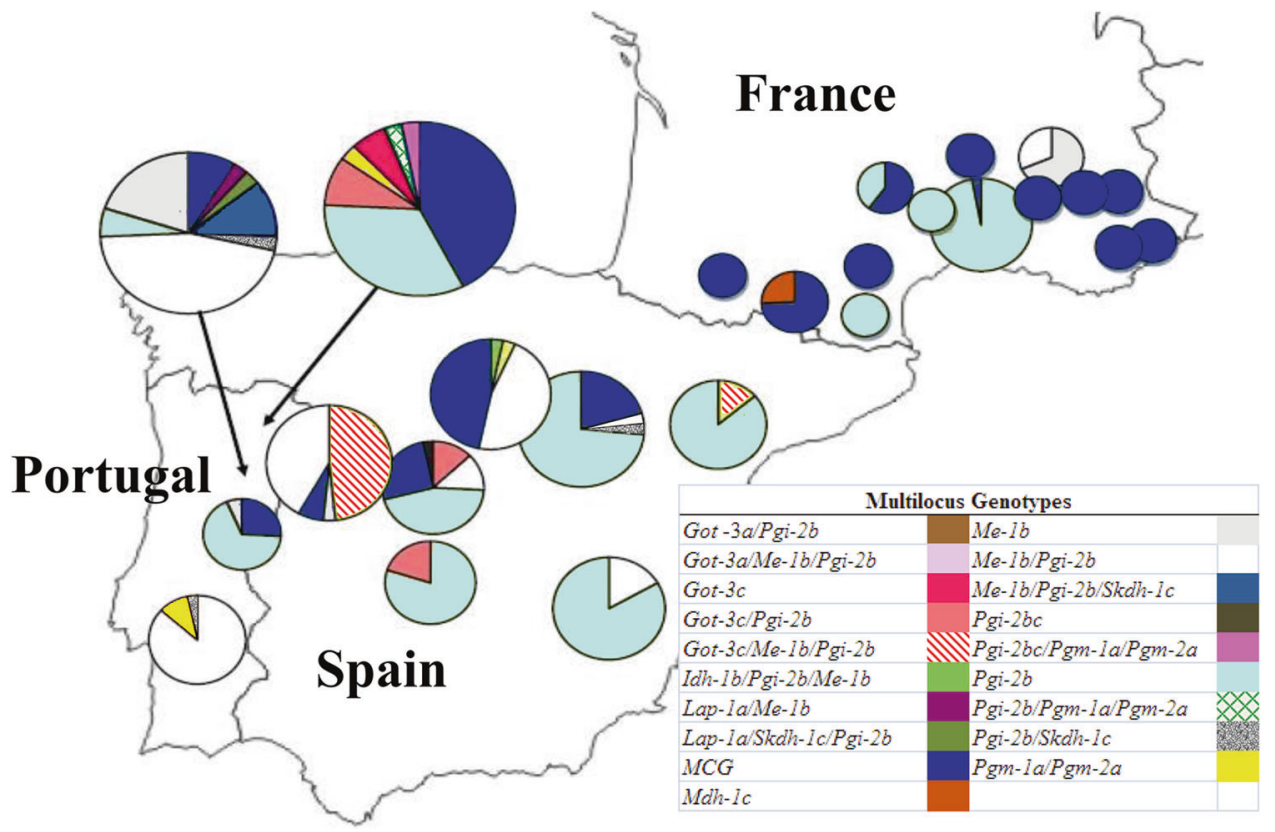

Fig. 2 Multilocus genotypes for 25 populations of Bromus tectorum from the western Mediterranean region. Pie diagrams illustrate the proportion of each multilocus genotype in each population. Larger pie diagrams are provided to enhance legibility and do not indicate any other population parameter (e.g., sample size).

only loci for which $G_{\text {ST }}$ values are $>0.500$ (Table 4). The partitioning of diversity among populations is similar between populations from the eastern and western Mediterranean regions $\left(G_{\mathrm{ST}}=0.208\right.$ and $G_{\mathrm{ST}}=0.257$, respectively) (Table 3 ) and slightly less than the value for all 42 populations $\left(G_{\mathrm{ST}}=0.279\right)$ (Table 4$)$.

Populations from the eastern Mediterranean are more similar to each other $(I=0.985)$ compared to populations from the western Mediterranean region $(I=0.973)$ (Supplementary Information Table 4). On average, populations from the eastern and western Mediterranean have the lowest genetic-identity value $(I=0.969)$. The genetic-identity values within and among populations from Israel, Jordan, and Syria (cf. $I=0.982-0.997$ ) are generally higher compared to values for the populations from southern France (cf. $I=$ 0.965-0.986) (Supplementary Information Table 5). Populations from the Iberian Peninsula (Spain and Portugal) have the lowest genetic similarity values (cf. $I=0.951-0.960$ ), compared with populations from all other regions.

The UPGMA cluster diagram, based on values of Nei's (1978) $I$, provides a graphic representation of the genetic relationships among these 42 populations (Fig. 4). The populations are grouped, based on their MLGs and to a lesser extent on their geographic distribution. For example, Clusters 1 and 2 contain populations that are either fixed for the MCG (Cluster 1) or have a relatively high frequency of the MCG (Cluster 2). In addition, Clusters 1 and 2 include populations from the eastern Mediterranean and western Mediterranean regions (Israel, Jordon, Syria, France, and Portugal). In contrast, all populations in Cluster 3 are from
Israel (Fig. 4), and these five populations have lower frequencies of the MCG and a higher frequency of the Got-4c and Got- $4 d$ genotypes. Clusters 4 and 5 include 10 populations from the Iberian Peninsula (three populations from Portugal and all seven Spanish populations), one population from Israel, and four populations from southern France. These populations have higher frequencies of the $P g i-2 b$ and $M e-1 b / P g i-2 b$ multilocus genotypes. The UPGMA phenograms constructed for populations from the eastern Mediterranean region (Supplementary Information Fig. 1) and the western Mediterranean regions (Supplementary Information Fig. 2) show a pattern similar to that of Fig. 4: populations are grouped based on their MLGs and to a lesser extent their geographic distribution.

\section{Discussion}

In this study, we employed allozymes to determine the level and structure of genetic diversity within and among populations of B. tectorum from the Mediterranean region to determine their biogeographical history. Specifically, we tested whether populations from the region bordering the eastern Mediterranean were more genetically diverse compared with populations from the western Mediterranean, a likely consequence of the species' westward dispersal with the spread of agriculture and other anthropogenic activities. Alternatively, these data allowed us to determine whether populations from the eastern and western Mediterranean contain comparable genetic diversity 
Table 2 Location of the 50 multilocus genotypes (MLGs) in the 42 populations of Bromus tectorum from the Mediterranean region (current study), and their distribution in 51 native Eurasian populations and 318 invasive populations from North America.

\begin{tabular}{|c|c|c|c|}
\hline Multilocus genotype & Current study & Eurasia & North America \\
\hline Most common genotype & 35 of 42 populations & 39 of 51 pops. & 299 of 318 pops. \\
\hline Got-3c & $\begin{array}{l}\text { Mas'ada, IL }(9.1 \%) \\
\text { MH foothills, IL }(5.9 \%) \\
\text { TDM, PT }(6.1 \%)\end{array}$ & Morocco (1) & No match \\
\hline$M e-1 b$ & $\begin{array}{l}\text { MS summit, IL }(47.1 \%) \\
\text { Retortilla, ES }(3.2 \%) \\
\text { Castelo B, PT }(6.8 \%) \\
\text { Minhocal, PT }(20 \%) \\
\text { St. Laurent, FR }(68.6 \%)\end{array}$ & No match & No match \\
\hline$M e-1 b / P g i-2 b$ & $\begin{array}{l}\text { MS summit, IL }(11.8 \%) \\
\text { Canamares, ES }(2.9 \%) \\
\text { Pedraza, ES }(46.7 \%) \\
\text { Retortillo, ES }(41.9 \%) \\
\text { Robledillo, ES }(12.9 \%) \\
\text { San Clemente, ES }(16.6 \%) \\
\text { Arronches, PT }(86.2 \%) \\
\text { Minhocal, PT }(45.7) \\
\text { St. Laurent, FR }(31.4 \%)\end{array}$ & No match & No match \\
\hline$P g i-2 b$ & $\begin{array}{l}\text { Mas'ada, IL (9.1\%) } \\
\text { MS summit, IL (11.8\%) } \\
\text { Pisgat, IL (5.9\%) } \\
\text { Shaal, IL (9.7\%) } \\
\text { Shobak Castle, JO (6.9\%) } \\
\text { Seynayda, SY (2.9\%) } \\
\text { Alarba, ES (86.2\%) } \\
\text { Canamares, ES (73.5\%) } \\
\text { Guadalupe, ES (80\%) } \\
\text { Robledillo, ES (45.2\%) } \\
\text { San Clemente, ES (83.3\%) } \\
\text { Castelo B, PT (67.7\%) } \\
\text { Minhocal, PT (5.7\%) } \\
\text { TDM, PT (33.3\%) } \\
\text { Bueges, FR (97.1\%) } \\
\text { Cabrespine, FR (40\%) } \\
\text { Fontfroide, FR (100\%) } \\
\text { Sournia, FR (100\%) }\end{array}$ & $\begin{array}{l}\text { Spain (4) } \\
\text { France (2) } \\
\text { Morocco (1) }\end{array}$ & $\begin{array}{l}\text { Western U.S. (4) } \\
\text { Southwest U.S. (7) }\end{array}$ \\
\hline Pgm-1a/Pgm-2a & $\begin{array}{l}\text { Petra Trail, JO (11.1\%) } \\
\text { TDM, PT (3\%) }\end{array}$ & $\begin{array}{l}\text { Hungary (1) } \\
\text { Slovakia (1) }\end{array}$ & $\begin{array}{l}\text { Eastern U.S. (4) } \\
\text { Midwest U.S. (33) } \\
\text { Midcontinent U.S. (24) } \\
\text { Western U.S. (2) } \\
\text { Southwest U.S. (3) } \\
\text { Canada (19) }\end{array}$ \\
\hline Adh-1a & $\begin{array}{l}\text { Jerusalem, IL }(2.9 \%) \\
\text { MH entrance, IL }(22.9 \%) \\
\text { MH station, IL }(5.7 \%) \\
\text { Ma'loula, SY }(32.4 \%)\end{array}$ & Turkey (1) & No match \\
\hline
\end{tabular}


Table 2 (continued)

\begin{tabular}{|c|c|c|c|}
\hline Multilocus genotype & Current study & Eurasia & North America \\
\hline$A d h-1 a / I d h-1 b$ & MH entrance, IL (2.9\%) & No match & No match \\
\hline Adh-1a/Got-1a/Got-2a & Ma'Loula, SY (2.9\%) & No match & No match \\
\hline$A d h-1 a / M d h-2 c / M d h-3 b$ & Jerusalem 2, IL (2.9\%) & No match & No match \\
\hline$G 6 p d h-2 b$ & MS summit, IL (2.9\%) & No match & No match \\
\hline G6pdh-2b/Me-1b & MS summit, IL (2.9\%) & No match & No match \\
\hline Got-1a/Got- $2 a$ & Ma'loula, SY (26.5\%) & No match & No match \\
\hline Got-3a/Pgi-2b & Arronches, PT (10.3\%) & No match & No match \\
\hline Got-3a/Me-1b/Pgi-2b & Arronches, PT (3.4\%) & No match & No match \\
\hline Got-3c/Got-4c & MH foothills, IL (11.8\%) & No match & No match \\
\hline Got-3c/Got-4d & MH foothills, IL (2.9\%) & No match & No match \\
\hline Got-3c/Pgi-2b & $\begin{array}{l}\text { Guadalupe, ES (20\%) } \\
\text { Robledillo, ES }(12.9 \%) \\
\text { TDM, PT }(9.1 \%)\end{array}$ & No match & No match \\
\hline Got $-3 c / M e-1 b / P g i-2 b$ & $\begin{array}{l}\text { Alarba, ES }(13.8 \%) \\
\text { Pedraza, ES }(33 \%) \\
\text { Retortillo, ES }(48.3 \%)\end{array}$ & No match & No match \\
\hline Got $-4 c$ & $\begin{array}{l}\text { MS summit, IL }(2.9 \%) \\
\text { Golan, IL }(40 \%) \\
\text { MH foothills, IL }(35.3 \%)\end{array}$ & $\begin{array}{l}\text { Germany (1) } \\
\text { Czech Republic (1) }\end{array}$ & $\begin{array}{l}\text { Midwest U.S. (3) } \\
\text { Midcontinent U.S. (1) } \\
\text { Western U.S. (34) } \\
\text { Southwest U.S. (25) } \\
\text { Canada (23) }\end{array}$ \\
\hline Got-4c/Me-1b & MS summit, IL (2.9\%) & No match & No match \\
\hline Got-4c/Pgi-2b & MS summit, IL (2.9\%) & No match & Southwest U.S. (1) \\
\hline Got-4d & $\begin{array}{l}\text { Golan, Il }(45.7 \%) \\
\text { Jerusalem 2, IL }(2.9 \%) \\
\text { Mas'ada, IL }(69.7 \%) \\
\text { MH foothills, IL }(8.8 \%) \\
\text { MS foothills, IL }(65.7 \%) \\
\text { Shaal, IL }(25.8 \%)\end{array}$ & No match & No match \\
\hline Got-4d/Lap-1a & Shaal, IL (2.6\%) & No match & No match \\
\hline Got-4d/Lap-1a/Pgi-2b & Shaal, IL (3.2\%) & No match & No match \\
\hline Got-4d/Mdh-2c/Mdh-3b & Jerusalem 2, IL (5.7\%) & No match & Mo match \\
\hline Got-4d/Me-1b & MS summit, IL (5.9\%) & No match & No match \\
\hline Got-4d/Pgi-2b & $\begin{array}{l}\text { Golan, IL }(11.4 \%) \\
\text { Mas'ada, IL }(6.1 \%) \\
\text { MS foothills, IL }(8.6 \%) \\
\text { Shaal, IL }(3.2 \%)\end{array}$ & No match & No match \\
\hline Got-4f & Petra Hotel, JO (14.7\%) & No match & No match \\
\hline$I d h-1 b$ & $\begin{array}{l}\text { MH entrance, IL }(22.9 \%) \\
\text { MH station, IL }(8.6 \%) \\
\text { Petra Hotel, JO }(2.9 \%)\end{array}$ & Iran (1) & No match \\
\hline$I d h-1 b / M d h-2 c$ & MH station, IL (2.9\%) & No match & No match \\
\hline$I d h-1 b / M e-1 b / P g i-2 b$ & Pedraza, ES (3.3\%) & No match & No match \\
\hline Idh-1b/Pgm-1c/Pgm-2c & MH entrance, IL (2.9\%) & No match & No match \\
\hline Lap-1a & $\begin{array}{l}\text { Shaal, IL }(12.9 \%) \\
\text { Petra Trail, JO }(29.6 \%)\end{array}$ & $\begin{array}{l}\text { Afghanistan (1) } \\
\text { Iran (2) } \\
\text { Soviet Union (1) }\end{array}$ & No match \\
\hline
\end{tabular}


Table 2 (continued)

\begin{tabular}{|c|c|c|c|}
\hline Multilocus genotype & Current study & Eurasia & North America \\
\hline Lap-1a/Me-1b & Minhocal, PT (2.9\%) & No match & No match \\
\hline Lap-1a/Pgi-2b/Skdh-1c & Minhocal, PT (2.9\%) & No match & No match \\
\hline$M d h-1 a / M d h-2 c / M d h-3 b$ & Jerusalem, 1, IL (2.9\%) & No match & No match \\
\hline Mdh-1a/Mdh-2c/Mdh-3b/Pgm-1c/Pgm-2c & Jerusalem 2, IL (2.9\%) & No match & No match \\
\hline$M d h-1 c$ & Monte-Louis, FR (25.7\%) & No match & No match \\
\hline$M d h-2 c$ & MH station, IL (2.9\%) & No match & No match \\
\hline$M d h-2 c / M d h-3 b$ & $\begin{array}{l}\text { Jerusalem 2, IL (20\%) } \\
\text { Pisgat, IL }(5.9 \%)\end{array}$ & No match & $\begin{array}{l}\text { Eastern U.S. (2) } \\
\text { Midwest U.S. (4) } \\
\text { Midcontinent U.S. (3) } \\
\text { Western U.S. (6) } \\
\text { Southwest U.S. (4) }\end{array}$ \\
\hline$M e-1 b / P g i-2 b / S k d h-1 c$ & Minhocal, PT (2.9\%) & No match & No match \\
\hline$P g i-2 b / S k d h-1 c$ & Minhocal, PT (11.4\%) & No match & No match \\
\hline Pgi-2b/Pgm-1a/Pgm-2a & TDM, PT (3\%) & No match & No match \\
\hline Pgi-2bc & $\begin{array}{l}\text { Canamares, ES }(2.9 \%) \\
\text { Robledillo, ES }(3.2 \%)\end{array}$ & Spain (1) & No match \\
\hline$P g i-2 b c / M e-1 b$ & MS summit, IL (2.9\%) & No match & No match \\
\hline Pgi-2bc/Pgm-1a/Pgm-2a & TDM, PT (3\%) & No match & No match \\
\hline$P g i-2 d$ & Ma'loula, SY (2.9\%) & No match & No match \\
\hline Pgm-1c/Pgm- $2 c$ & MH entrance, IL (2.9\%) & No match & No match \\
\hline$S k d h-1 a$ & Petra Trail, JO (3.7\%) & Morocco (1) & No match \\
\hline
\end{tabular}

The first six multilocus genotypes listed in this table were detected in populations from both the eastern and western Mediterranean. For populations listed under the current study, the number in parentheses indicates the frequency of the multilocus genotype in the population. For populations listed under Eurasia and North America, the number in parentheses indicates the number of populations with that multilocus genotype. Data for populations from Eurasia were from Novak and Mack (1993), and data for populations from North America were from Novak and Mack (2016). Population acronyms are as given in Supplemental Information Table 1.

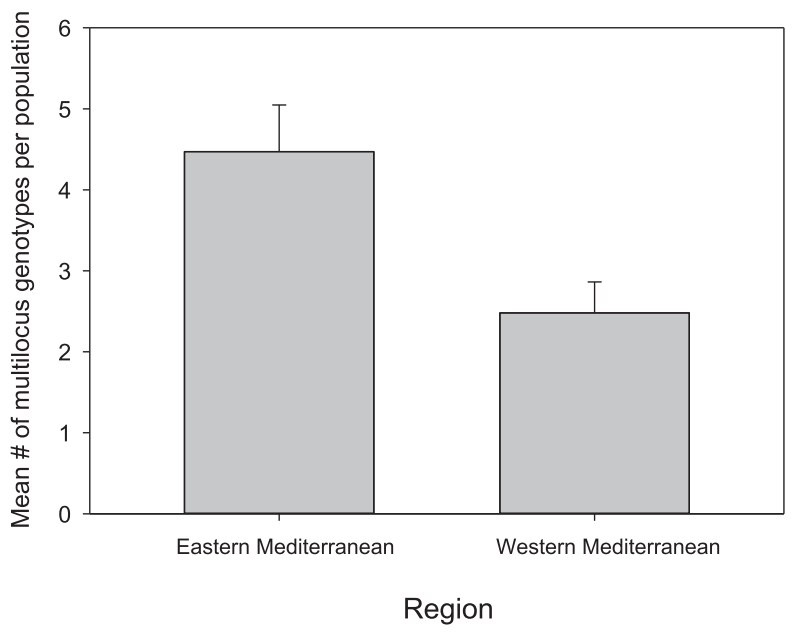

Fig. 3 The mean number of multilocus genotypes per population of Bromus tectorum from the eastern Mediterranean and western Mediterranean regions. Differences in the number of multilocus genotypes per population in these two regions are statistically significant $(P=0.002)$.

and relatively high genetic differentiation, potentially a result of both regions having served as refugia during glacial advances in the late Quaternary Period. The higher number of multilocus genotypes and the higher level of genetic diversity detected among and within populations of the eastern Mediterranean is generally consistent with the first scenario described above. These results suggest that the dispersal of $B$. tectorum with the east-west spread of agriculture in the Holocene Period has been a predominant factor determining this grass's genetic diversity in the Mediterranean region. Our findings are consistent with other studies that have assessed the biogeographic or phylogeographic pattern of ruderal species associated with agriculture (see below).

\section{Biogeographical pattern: role of anthropogenic activity}

From its inception, crop cultivation has been accompanied by the establishment and evolution of weeds within the agricultural environment (Zohary and Hopf 2000). For example, charred remains of bromes are entombed in sediments at sites of early cultivation in northern Syria, indicating these species' likely association with humans and 
Table 3 Parameters describing genetic diversity and structure for Bromus tectorum populations from different regions in the native range.

\begin{tabular}{lcllllll}
\hline Region & Populations & \multicolumn{1}{l}{$A$} & \multicolumn{1}{l}{$\%$} & \multicolumn{1}{l}{$H_{\mathrm{exp}}$} & \multicolumn{1}{l}{$H_{\text {obs }}$} & $H_{\mathrm{T}}$ \\
\hline Israel & 11 & $1.13(0.017)$ & $13.45(1.729)$ & $0.032(0.004)$ & $0.00012(0.00009)$ & $0.092(0.039)$ & $0.199(0.039)$ \\
Jordan & 3 & $1.09(0.035)$ & $9.33(3.528)$ & $0.018(0.012)$ & $0.00000(0.00000)$ & $0.072(0.031)$ & $0.065(0.013)$ \\
Syria & 3 & $1.07(0.048)$ & $6.67(4.807)$ & $0.019(0.018)$ & $0.00000(0.00000)$ & $0.150(0.064)$ & $0.167(0.033)$ \\
E. Mediterranean region & 17 & $1.12(0.067)$ & $11.53(1.567)$ & $0.027(0.004)$ & $0.00008(0.00006)$ & $0.064(0.027)$ & $0.208(0.041)$ \\
Spain & 7 & $1.09(0.014)$ & $8.57(1.360)$ & $0.022(0.003)$ & $0.00018(0.00018)$ & $0.240(0.102)$ & $0.274(0.130)$ \\
Portugal & 4 & $1.12(0.023)$ & $12.00(2.309)$ & $0.033(0.008)$ & $0.00031(0.00025)$ & $0.176(0.075)$ & $0.162(0.032)$ \\
Iberian Peninsula & 11 & $1.11(0.012)$ & $9.82(1.249)$ & $0.026(0.004)$ & $0.00011(0.00014)$ & $0.208(0.088)$ & $0.218(0.043)$ \\
Southern France & 14 & $1.01(0.005)$ & $1.14(0.501)$ & $0.004(0.002)$ & $0.00000(0.00000)$ & $0.186(0.079)$ & $0.684(0.136)$ \\
W. Mediterranean region & 25 & $1.05(0.011)$ & $4.96(1.065)$ & $0.014(0.003)$ & $0.00005(0.00007)$ & $0.109(0.046)$ & $0.257(0.051)$ \\
Europe & 39 & $1.01(0.005)$ & $1.64(0.481)$ & $0.006(0.002)$ & $0.00010(0.00007)$ & $0.069(0.029)$ & $0.656(0.130)$ \\
SW Asia & 12 & $1.03(0.018)$ & $3.67(1.806)$ & $0.013(0.002)$ & $0.00020(0.00182)$ & $0.201(0.085)$ & $0.735(0.146)$ \\
\hline
\end{tabular}

Parameters are the mean number of alleles per locus $(A)$, the percent polymorphic loci $(\% P)$, the expected mean heterozygosity per locus $\left(H_{\text {exp }}\right)$, the mean observed heterozygosity per locus $\left(H_{\mathrm{obs}}\right)$, the total gene (allelic) diversity $\left(H_{\mathrm{T}}\right)$, and the proportion of the total gene diversity partitioned among populations $\left(G_{\mathrm{ST}}\right)$. Values for populations from Europe and SW Asia were reported in Novak and Mack (1993) and summarized in Pawlak et al. 2015. Standard errors are given in parentheses.

Table $4 \mathrm{~F}$ statistics and the hierarchical partitioning of gene diversity (Nei 1973, 1977) for 16 polymorphic loci detected in 42 populations of Bromus tectorum from the Mediterranean region.

\begin{tabular}{lllllll}
\hline Locus & $F_{\mathrm{IT}}$ & $F_{\mathrm{IS}}$ & $H_{\mathrm{T}}$ & $H_{\mathrm{S}}$ & $D_{\mathrm{ST}}$ & $G_{\mathrm{ST}}$ \\
\hline Adh & 1.000 & 1.000 & 0.0066 & 0.0050 & 0.00163 & 0.2460 \\
G6pdh-1 & 1.000 & 1.000 & 0.0028 & 0.0028 & 0.00001 & 0.0040 \\
Got-1 & 1.000 & 1.000 & 0.0139 & 0.0100 & 0.00388 & 0.2790 \\
Got-2 & 1.000 & 1.000 & 0.0139 & 0.0100 & 0.00388 & 0.2790 \\
Got-3 & 1.000 & 1.000 & 0.0709 & 0.0553 & 0.01560 & 0.2200 \\
Got-4 & 1.000 & 1.000 & 0.1611 & 0.0722 & 0.08894 & 0.5520 \\
Idh & 1.000 & 1.000 & 0.0219 & 0.0177 & 0.00411 & 0.1880 \\
Lap & 1.000 & 1.000 & 0.0346 & 0.0242 & 0.01046 & 0.3020 \\
Mdh-1 & 1.000 & 1.000 & 0.0149 & 0.0119 & 0.00297 & 0.1990 \\
Mdh-2 & 1.000 & 1.000 & 0.0230 & 0.0183 & 0.00474 & 0.2060 \\
Mdh-3 & 1.000 & 1.000 & 0.0204 & 0.0157 & 0.00468 & 0.2300 \\
Me & 1.000 & 1.000 & 0.2384 & 0.0489 & 0.18950 & 0.7950 \\
Pgi-2 & 0.977 & 0.993 & 0.4364 & 0.1296 & 0.30682 & 0.7030 \\
Pgm-1 & 1.000 & 1.000 & 0.0136 & 0.0127 & 0.00090 & 0.0660 \\
Pgm-2 & 1.000 & 1.000 & 0.0136 & 0.0127 & 0.00090 & 0.0660 \\
Skdh & 1.000 & 1.000 & 0.0099 & 0.0086 & 0.00129 & 0.1310 \\
Mean & 0.999 & 1.000 & 0.0685 & 0.0285 & 0.04002 & 0.2791 \\
\hline F & & & & & &
\end{tabular}

$F_{\text {IT }}$ values of 1.0 indicate a complete deviation from random mating across populations for each locus, while $F_{\text {IS }}$ values of 1.0 indicate a complete deviation from random mating within populations for each locus. Total gene diversity $\left(H_{\mathrm{T}}\right)$ is partitioned into the withinpopulation component $\left(H_{\mathrm{S}}\right)$ and the among-population component $\left(D_{\mathrm{ST}}\right) . G_{\mathrm{ST}}$ is the portion of the total gene diversity partitioned among populations.

crops since 9000 -year BCE (Willcox et al. 2008). Our results are consistent with a view that human activity, possibly beginning as early as the Neolithic Age, fostered the dispersal of $B$. tectorum west from the Fertile Crescent across the Mediterranean region. The lower number of multilocus genotypes, alleles per locus, polymorphic loci, and expected heterozygosity among populations from the western compared with eastern Mediterranean populations is consistent with founder effects that were in turn coincident with the western movement of agriculture (Sirkkomaa 1983) (Table 3). Our findings complement the results reported by Oja (1999), who also characterized allozyme variation in B. tectorum in the Middle East (Turkey and Syria), western and central Europe, and western Asiatic Russia. Though sampling by Oja (1999) was sparse (e.g., only three Spanish populations were examined, and only one each in Italy, Greece, and Hungary), lower allozyme variability from east to west was nonetheless detected.

Even though $B$. tectorum populations display a lower number of polymorphic loci and MLGs in the western Mediterranean region (Figs. 1-3), other measures of genetic diversity indicate that populations in the Iberian Peninsula are likely the descendants of a large founder population, multiple introduction events, or both. For example, the mean number of alleles per locus is similar for populations from the Iberian Peninsula (1.11) and the eastern Mediterranean (1.12) (Table 3). Based on theoretical models, (Nei et al. 1975, Widmer and Lexer 2001), allelic diversity is a more sensitive indicator of founder effects when compared with other measures of genetic diversity, such as observed heterozygosity and percent polymorphic loci. This sensitivity is especially prominent when low-frequency alleles are present in the source population(s). However, the similarity between these genetic diversity parameters provides evidence against a strong founder effect occurring between populations in the eastern Mediterranean and the Iberian Peninsula (Table 3). 
Fig. 4 Unweighted pair-group method with arithmetic averaging (UPGMA) phenogram for 42 populations of Bromus tectorum from the Mediterranean region. The UPGMA phenogram is based on unbiased genetic-identity values for the populations (Nei 1978).

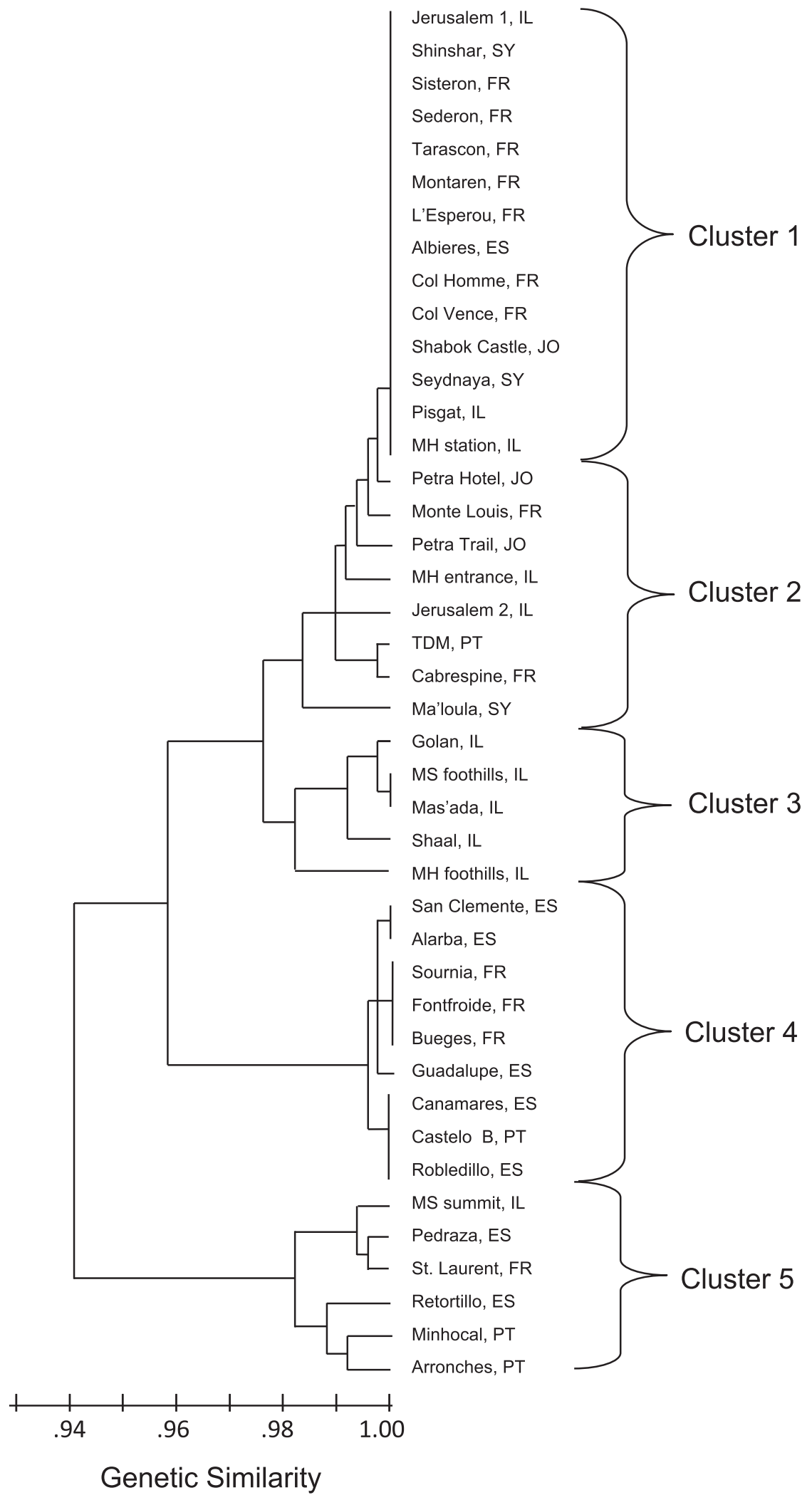

Historical evidence provides a compelling explanation for the means and locales by which $B$. tectorum was spread across the Mediterranean region. By at least 7000 year, BCE cargo was being transported across the eastern Mediterranean Sea (Abulafia 2011 and refs. therein). Although the spread of agriculture made crop cultivation commonplace, many coastal 
and western Mediterranean settlements still required imported food, especially grains. Wheat was exported primarily from the Nile Valley, the Pontic coast, Syria, and Cyprus (Semple 1921). By 800-year BCE, Phoenicians had established settlements across the southern coast of Spain and France, with shipping routes connecting the Levant and the Iberian Peninsula along with North Africa and the Italian Peninsula (Morgenroth 1999; Norwich 2006). Wheat was also grown on the Iberian Peninsula as well as in Italy, including Sicily, and locally in North Africa (Semple 1921; Abulafia 2011). Establishment of these regions for the production and export of cereals simultaneously provided opportunities for crop weeds, such as B. tectorum, to be dispersed and persist.

Similarities between the population genetics and evolutionary and agricultural history of $B$. tectorum and other primarily self-pollinating grasses (e.g., A. barbata [slender wild oat], Hordeum spontaneum [wild barley], L. perenne [perennial ryegrass], and L. rigidum [annual ryegrass]), suggest that all five species share a common scenario for their origin and subsequent spread. H. spontaneum is a wild progenitor of a crop from the Fertile Crescent. Genetic analyses reveal that $51 \%$ of its alleles are unique to Israel, Turkey, and Iran with a high proportion of common alleles detected sporadically (Nevo et al. 1986). Populations of $H$. spontaneum in western Asia had a higher degree of allozyme polymorphism than European populations (Kahler and Allard 1981). In addition, higher levels of genetic diversity have also been reported for populations of A. barbata from Israel compared to the diversity reported for Spanish populations (Kahler et al. 1980; Garcia et al. 1989).

Similarly, higher levels of genetic diversity were reported within populations of $L$. perenne from the eastern Mediterranean (Turkey, Lebanon, and Cyprus), Iraq, Iran, and southern and central Italy, compared with populations from Spain, Portugal, and southwestern France (Balfourier et al. 1998). For L. rigidum, the same pattern was observed for the number of alleles per locus, but not for other genetic diversity parameters. Populations of $L$. perenne and $L$. rigidum from the Mediterranean region had higher genetic diversity compared with populations from northern and western Europe. Balfourier et al. (1998) indicated that their data are consistent with the westward dispersal of both species from the Fertile Crescent across the Mediterranean and northward into Europe with the spread of agriculture, but they did not reject explicitly the hypothesis that both species may also have spread into northern and western Europe during postglacial recolonization from southern refugia.

\section{Biogeographical pattern: role of glacial history}

As noted above, an alternative (but not mutually exclusive) explanation for the genetic diversity and structure of
B. tectorum in the Mediterranean region places its occurrence in the Iberian Peninsula glacial refugium before the onset of the last Weichselian glacial maximum $(\approx 18,000$ $\mathrm{BCE})$. Subsequently, species restricted to the glacial refugium in the Iberian Peninsula and other refugia in the Italian and Balkan Peninsulas recolonized central and northern Europe. Evidence for the influence of Quaternary glaciation on the genetic diversity among contemporary populations broadly distributed across Europe includes higher genetic diversity within refugial populations than populations located at more northerly latitudes. In addition, protracted genetic isolation would also produce high genetic differentiation (also described as reciprocal monophyly) among populations in different refugia (Taberlet et al. 1998; Hewitt 2000; Valdiosera et al. 2007). Alternatively, Comps et al. (2001) and Petit et al. (2003) have shown that the genetic diversity of populations from central and northern Europe is greater than refugial populations due to admixture, which occurred as divergent lineages intermixed during postglacial recolonization.

Genetic diversity of $11 \mathrm{~B}$. tectorum populations from the Iberian Peninsula analyzed in this study (Table 3; $A=1.11$, $P=2.45, \quad \% P=9.82, \quad H_{\exp }=0.022, \quad$ MLGs $\left.=4.00\right) \quad$ is indeed higher than that found within populations previously analyzed in central and northern Europe. Seventeen of 39 European populations analyzed by Novak and Mack (1993) were sampled from central and northern Europe localities, and the within-population genetic diversity of these 17 populations $\left(A=1.01, P=0.35, \% P=1.41, H_{\text {exp }}=0.004\right.$, MLGs $=1.24$ ) indicates a reduction in diversity as the species migrated northward following the last glacial maxima. Of these 17 central and northern European populations, 13 populations exhibited no allozyme diversity and were fixed for the MCG (Novak and Mack 1993). Similar to our results, Oja (1999) indicated that eight of the ten populations of B. tectorum sampled in Germany and one population from Hungary were fixed for the most commonly detected lineage. These data are consistent with the population genetics associated with the postglacial recolonization of central and northern Europe from a putative glacial refugia such as the Iberian Peninsula (Taberlet et al. 1998; Hewitt 1999, 2000).

Three glacial refugia in southern Europe (the Iberian, Italian, and Balkan Peninsulas) along with several cryptic glacial refugia elsewhere in Europe have been proposed, based on genetic analyses among plants and animals (Taberlet et al. 1998; Hewitt 2000, 2011). The cryptic refugia include regions in southern France, western Europe, sites bordering the English Channel, the Carpathian Mountains, Turkey, and the Middle East (Provan and Bennett 2008; Medail and Diadema 2009; Schmidt and Varga 2012; Boston et al. 2015). The genetic diversity of 14 populations of $B$. tectorum from southern France we 
analyzed here is lower than the diversity of 11 populations from the Iberian Peninsula (Tables 2 and 3). Furthermore, the MLGs detected in the populations from southern France are largely a subset of genotypes found among the Iberian Peninsula populations (Fig. 2). These results suggest that the genetic diversity of $B$. tectorum populations in southern France may have been influenced by founder effects associated with the northward colonization of the grass from the Iberian Peninsula, following the most recent glacial retreat. These results are inconsistent with southern France having served as a glacial refugia for $B$. tectorum.

The Middle East (Israel) has also been proposed as a glacial refugium in addition to the three southern European refugia (Balfourier et al. 1998; Hewitt 1999; Medail and Diadema 2009). Populations from Israel, Jordan, and Syria have, on average, the highest levels of genetic diversity that we have ever detected; the diversity of eastern Mediterranean populations of $B$. tectorum is much higher than the diversity of populations from northern and central Europe (Table 3).

In addition to higher genetic diversity within refugial populations than populations at more northerly latitudes, evidence for the influence of glaciation is also provided by high genetic differentiation among populations in different refugia (Taberlet et al. 1998; Hewitt 2000; Valdiosera et al. 2007). However, populations from the eastern Mediterranean and the Iberian Peninsula (the western Mediterranean) lack high genetic differentiation. The mean value of $G_{\mathrm{ST}}$ among all 42 populations analyzed here was 0.279 and indicates that only $27.9 \%$ of the total gene diversity is partitioned among populations (Table 4). In addition, multiple clusters in the UPGMA diagram contain populations from across the Mediterranean region (Fig. 4). For instance, Clusters 1 and 2 include populations from the eastern and western Mediterranean regions. Cluster 5 includes one population each from the eastern Mediterranean Region and southern France, and four populations from the Iberian Peninsula. These results likely stem from the high frequencies of the MCG widely observed in $B$. tectorum populations from these regions, and the high frequencies of the $P g i-2 b$ and $M e-1 b / P g i-2 b$ MLGs in populations from the Iberian Peninsula and the Mt. Shifon summit population in Israel (Figs. 1 and 2). Taken together, our results do not rule out entirely that both the eastern Mediterranean region and the Iberian Peninsula served as glacial refugia for B. tectorum, from which recolonization of central and northern Europe may have occurred.

\section{Consequences of outcrossing in a predominantly self-pollinating species}

Detection of four heterozygotes in our study and the heterozygosity observed in B. tectorum in other areas (see Novak and Mack 2016) supports the conclusion that $B$. tectorum is not an "obligate selfer" as proposed by McKone
1985. In addition, our data likely underestimate the degree of outcrossing because the progeny of crosses between individuals with the same MLG(s) will be identical to progeny produced through self-pollination. Outcrossing events in $B$. tectorum, although rare, have not only produced a handful of heterozygous individuals, but these events have also generated novel, recombinant MLGs. Such MLGs have contributed to the genetic diversity within and among populations from the eastern and western Mediterranean regions (Figs. 1 and 2). For example, low-frequency MLGs in the Mt. Shifon summit, Israel population (G6pdh-2b/Me$1 b$, Got-4c/Me-1b, and Got-4d/Pgi-2b), the Minhocal, Portugal population (Lap-1a/Pgi-2b/Skdh-1c and Me-1b/Pgi-2b/ $S k d h-1 c$ ), and other populations (see Table 2) are likely novel, recombinant genotypes. Occasional outcrossing reshuffles the allelic (genetic) diversity of this highly selfing species, generates recombinant MLGs, and likely contributes to the adaptive potential of populations.

\section{Influence of environmental heterogeneity}

The nine polymorphic loci we detected in the western Mediterranean populations of $B$. tectorum are a subset of 16 polymorphic loci detected among eastern Mediterranean populations, but only six of the 50 MLGs detected among all populations are shared between these two regions. Prolonged east-west genetic isolation among populations can result in speciation and endemism. Differentiation can also occur in refugial populations without glaciation, e.g., through changes in the annual distribution of precipitation (Thompson 2005). The climates along coastal Syria, Jordan, and Israel, as well as southern portions of the Iberian Peninsula, all exhibit maximum precipitation in winter. But precipitation in the Iberian Peninsula varies nevertheless from autumn, spring and autumn, or winter and spring (Esler et al. 2018). In addition, the characteristically dry summer is not necessarily rainless in the western Mediterranean region. In contrast, the eastern Mediterranean region often experiences summers with high temperatures and prolonged drought (Dallman 1998). The paucity of shared MLGs between the two regions' populations could be partially due to their different climates. For example, a link between adaptive gene complexes and habitat conditions, such as available moisture, has been detected in A. barbata (Garcia et al. 1989).

Environmental variation and allozyme variability have been linked elsewhere for self-pollinating plants (Nevo et al. 1998), although such genetic variability may have no adaptive significance. For example, Volis et al. (2003) found that MLGs in H. spontaneum are not favored based on habitat conditions; allozyme variation more closely follows a pattern of isolation-by-distance. In other plant species, allozyme variation is also consistent with neutrality 
(Jaramillo-Correa et al. 2001). Thus, the neutrality of allozyme markers can vary among species, and can be dependent on the environment (Dykhuizen and Hartl 1983).

\section{Conclusions}

The lower allelic diversity, number of polymorphic loci, and MLGs from east to west across the Mediterranean region are consistent with the spread of $B$. tectorum with early agriculture from the Fertile Crescent, although the role of Pleistocene glaciation cannot be completely excluded. The genetic diversity of Iberian Peninsula populations may have been boosted by later maritime trade. Further evidence for the east-to-west spread includes the low number of MLGs shared between regions (6), and a degree of divergence based on Nei's genetic-identity value (0.969). More comprehensive geographic sampling in the native range, coupled with use of additional genetic markers (Rowe et al. 2017), would likely facilitate the differentiation between these two hypotheses. Alternatively, both phenomena may have played a role in shaping current patterns of genetic diversity and structure; the future challenge will be to parse out the relative contribution of each scenario, as well as identify and quantify the ecological and evolutionary processes that have shaped the genetic diversity of $B$. tectorum in its native range.

\section{Data availability}

Data available from the Dryad Digital Repository: https:// doi.org/10.5061/dryad.7sqv9s4qq.

Acknowledgements We thank Alma Hodzic, Jeremiah Busch, Angela Pawlak, Justin Poinsatte, Chuck Cody, Karin Harrington, Rich Scott, Tim Tranbarger, and Rene F.H. Sforza for assistance at various stages in the research. Many populations analyzed in this study were collected while SJN was on sabbatical leave at the CSIRO European Laboratory near Montpellier, France. Funds for the research were provided to LJK through the Betty W. Higinbotham Trust in the School of Biological Sciences at Washington State University. Additional funds for this project were provided by USDA NIFA research grant 2008-35320-04555 to SJN.

\section{Compliance with ethical standards}

Conflict of interest The authors declare that they have no conflict of interest.

Publisher's note Springer Nature remains neutral with regard to jurisdictional claims in published maps and institutional affiliations.

\section{References}

Abulafia D (2011) The Great Sea: a human history of the Mediterranean. Oxford University Press, New York
Allen PS, Meyer SE (2002) Ecology and ecological genetics of seed dormancy in downy brome. Weed Sci 50:241-247

Balfourier F, Charmet G, Ravel C (1998) Genetic differentiation within and between natural populations of perennial and annual ryegrass (Lolium perenne and $L$. rigidum). Heredity 81:100-110

Blondel, J, Medail F (2009) Mediterranean biodiversity and conservation. In: Woodward JC (ed) The physical geography of the Mediterranean, Oxford University Press, New York, p 615-650

Boston ESM, Montgomery WI, Hynes R, Prodohl PA (2015) New insights on postglacial colonization in western Europe: the phylogeography of the Leisler's bat (Nyctalus leisleri). Proc R Soc B 28:20142605. https://doi.org/10.1098/rspb.2014.2605

Brown T, Jones M, Powell W, Allaby R (2009) The complex origins of domesticated crops in the Fertile Crescent. Trends Ecol Evol 24:103-109

Comes HP (2004) The Mediterranean region-a hot spot of plant ragwort, Senecio gallicus (Asteraceae). Evolution 52:355-67

Comps B, Gomory D, Letouzey J, Thiebault B, Petit RJ (2001) Diverging trends between heterozygosity and allelic richness during postglacial colonizing in the European beech. Genetics 157:389-397

Dallman PR (1998) Plant life in the world's Mediterranean climates: the Mediterranean Basin, South Africa, Australia, Chile, and California. Oxford University Press, New York

Dykhuizen DE, Hartl DL (1983) Functional effects of PGI allozymes in Escherichia coli. Genetics 105:1-18

Erskine W, Smartt J, Muehlbauer FJ (1994) Mimicry of lentil and the domestication of common vetch and grass pea. Econ Bot 48:326-332

Esler KJ, Jacobsen AL, Pratt RB (2018) Characteristics of Mediterranean-type ecosystems. In: Esler KJ, Jacobsen AL, Pratt RB (eds) The biology of Mediterranean-type ecosystems. Oxford University Press, New York, p 23-65

Garcia P, Vences FJ, Perez de la Vega M, Allard RW (1989) Allelic and genotypic composition of ancestral Spanish and colonial Californian gene pools of Avena barbata: evolutionary implications. Genetics 122:687-694

Greuter W (1991) Botanical diversity, endemism, rarity, and extinction in the Mediterranean area: an analysis based on the published volumes of the Med-checklist. Bot Chron 10:63-79

Hewitt GM (1999) Post-glacial re-colonization of European biota. Biol J Linn Soc 68:87-112

Hewitt GM (2000) The genetic legacy of Quarternary ice ages. Nature 405:907-913

Hewitt GM (2011) Mediterranean peninsulas: the evolution of hotspots. In: Zachos FE, Habel JC (eds) Biodiversity hotspots, Springer, Berlin, p 123-147

Huttanus TD, Novak SJ, Mack RN (2011) Propagule pressure and introduction pathways of Bromus tectorum (Cheatgrass; Poaceae) in the central United States. Int J Plant Sci 172:783-794

Jaramillo-Correa JP, Beaulieu J, Bousquet J (2001) Contrasting evolutionary forces driving population structure at expressed sequence tag polymorphisms, allozymes and quantitative traits in white spruce. Mol Ecol 10:2729-2740

Kahler A, Allard R (1981) Worldwide patterns of genetic variation among four esterase loci in barley (Hordeum vulgare L.). Theor Appl Genet 59:101-111

Kahler A, Allard R, Krzakowa M, Wehrhahn C, Nevo E (1980) Associations between isozyme phenotypes and environment in the slender wild oat (Avena barbata) in Israel. Theor Appl Genet $56: 31-47$

Mack RN (2011) Fifty years of 'Waging war on cheatgrass': research advances, while meaningful control languishes. In: Richardson DM (ed) Fifty years of invasion ecology: the legacy of Charles Elton, Wiley-Blackwell, Oxford, p 253-265 
McKone MJ (1985) Reproductive biology of several bromegrasses (Bromus): breeding system, pattern of fruit maturation, and seed set. Am J Bot 72:1334-1339

Medail F, Diadema K (2009) Glacial refugia influence plant diversity patterns in the Mediterranean Basin. J Biogeogr 36:1333-1345

Medail F, Quezel P (1997) Hot-spots analysis for the conservation of plant biodiversity in the Mediterranean Basin. Ann Mo Bot Gard $84: 112-127$

Morgenroth U (1999) Southern Iberia and the Mediterranean traderoutes. Oxf J Archaeol 18:395-401

Myers N, Mittermeier RA, Mittermeier CG, da Fonseca GAB, Kent J (2000) Biodiversity hotspots for conservation priorities. Nature 403:853-858

Nei M (1973) Analysis of gene diversity in subdivided populations. Proc Natl Acad Sci USA 70:3321-3323

Nei M (1977) F-statistics and analysis of gene diversity in subdivided populations. Ann Hum Genet 41:225-233

Nei M (1978) Estimation of average heterozygosity and genetic distance from a small number of individuals. Genetics 89:583-590

Nei M, Maruyama T, Chakraborty R (1975) The bottleneck effect and genetic variability in populations. Evolution 29:1-10

Nevo E, Baum B, Beiles A, Johnson DA (1998) Ecological correlates of RAPD DNA diversity of wild barley, Hordeum spontaneum, in the Fertile Crescent. Genet Res Crop Evol 45:151-159

Nevo E, Beiles A, Zohary D (1986) Genetic resources of wild barley in the Near East: structure, evolution and application in breeding. Biol J Linn Soc 27:355-380

Nieto Feliner G (2014) Patterns and processes in plant phylogeography in the Mediterranean Basin. A review. Perspect Plant Ecol Evol Syst 16:265-278

Norwich JJ (2006) The Middle Sea: a history of the Mediterranean. Doubleday, New York

Novak SJ, Mack RN (1993) Genetic variation in Bromus tectorum (Poaceae): comparison between native and introduced populations. Heredity 71:167-176

Novak SJ, Mack RN (2016) Mating system, introduction and genetic diversity of Bromus tectorum in North America, the most notorious product of evolution within Bromus section Genea. In: Germino M, Brown C, Chambers J (eds) Exotic annual Bromus grasses in semiarid ecosystems of the Western US: assessing causes, consequences, and management alternatives, Springer: Zurich, p 99-132

Novak SJ, Mack RN, Soltis DS (1991) Genetic variation in Bromus tectorum (Poaceae): population differentiation in its North America range. Am J Bot 78:1150-1162

Oja T (1999) Allozyme diversity and interspecific differentiation of the two diploid bromegrass species, Bromus tectorum L. and B. sterilis L. (Poaceae). Plant Biol 1:679-686

Pawlak AR, Mack RN, Busch JW, Novak SJ (2015) Invasions of Bromus tectorum (L.) into California and the American Southwest: rapid, multi-directional and genetically diverse. Biol Invasions 17:287-306

Petit RJ, Aquinagalde I, De Beaulieu BJL, Bittkau C, Brewer S, Cheddadi R et al. (2003) Glacial refugia: hotspots but not melting pots of genetic diversity. Science 300:1563-1565

Pierson EA, Mack RN (1990) The population biology of Bromus tectorum in forests: distinguishing the opportunity for dispersal from environmental restriction. Oecologia 84:519-525

Pinhasi R, Fort J, Ammerman AJ (2005) Tracing the origin and spread of agriculture in Europe. PLoS Biol 3:e410. https://doi.org/10. 1371/journal.pbio.0030410

Post GE, Dinsmore JE (1933) Flora of Syria, Palestine and Sinai: a handbook of the flowering plants and ferns, native and naturalized from the Taurus to Ras Muhammad and from the Mediterranean Sea to the Syrian desert. American Press, Beirut

Provan J, Bennett KD (2008) Phylogeographic insights into cryptic glacial refugia. Trends Ecol Evol 23:564-571

Rowe G, Sweet M, Beebee TJC (2017) An introduction to molecular ecology, 3rd edn. Oxford University Press, Oxford

Schachner LJ, Mack RN, Novak SJ (2008) Bromus tectorum (Poaceae) in midcontinental United States: population genetic analysis of an ongoing invasion. Am J Bot 95:1584-1595

Schmidt T, Varga Z (2012) Extra-Mediterranean refugia: the rule and not the exception? Front Zoo 9:22. http://www.frontiersinzoology. com/content/9/1/22

Semple EC (1921) Geographic factors in the ancient Mediterranean grain trade. Ann Assoc Am Geographers 11:47-74

Sirkkomaa S (1983) Calculations on the decrease of genetic variation due to the founder effect. Hereditas 99:11-20

Soltis DE, Haufler CH, Darrow DC, Gastony GJ (1983) Starch gel electrophoresis of ferns: a compilation of grinding buffers, gel and electrode buffers, and staining schedules. Am Fern J 73:9-27

Swofford DL, Selander RB (1989) BIOSYS-1. A computer program for the analysis of allelic variation in population genetics and biochemical systematics. University of Illinois, Urbana, Illinois, Release 1.7

Taberlet P, Fumagalli L, Wust-Saucy AG, Cosson JF (1998) Comparative phylogeography and postglacial colonization routes in Europe. Mol Ecol 7:453-464

Thompson JD (2005) Plant evolution in the Mediterranean. Oxford University Press, New York

Valdiosera CE, Garcia N, Anderung C, Dalen L, Crégut-Bonnoure E, Kahlke R-D (2007) Staying out in the cold: glacial refugia and mitochondrial DNA phylogeography in ancient European brown bears. Mol Ecol 16:5140-5148

Valliant MT, Mack RN, Novak SJ (2007) Introduction history and population genetics of the invasive grass Bromus tectorum (Poaceae) in Canada. Am J Bot 94:1156-1169

Volis S, Shulgina I, Ward D, Mendlinger S (2003) Regional subdivision in wild barley allozyme variation: adaptive or neutral? $\mathrm{J}$ Heredity 94:341-351

Widmer A, Lexer C (2001) Glacial refugia: sanctuaries for allelic richness, but not for gene diversity. Trends Ecol Evol $16: 267-269$

Willcox G, Fornite S, Herveux L (2008) Early Holocene cultivation before domestication in northern Syria. Veg Hist Archaeobotany $17: 313-25$

Willkomm M, Lange J (1870) Prodromus florae Hispanicae seu synopsis methodica omnium plantarum in Hispania sponte nascentium vel frequentius cultarum quae innotuerunt. Stuttgartie: Germania

Wright $S$ (1965) The interpretation of population structure by $F$-statistics with special regard to systems of mating. Evolution 19:395-420

Wright S (1978) Evolution and the genetics of population. Variability within and among natural populations. University of Chicago Press, Chicago

Zeder MA (2008) Domestication and early agriculture in the Mediterranean Basin: origins, diffusion, and impact. Proc Natl Acad Sci USA 105:11597-11604

Zohary M, Feinbrun-Dothan N (1966) Flora Palaestina. Israel Academy of Science and Humanities, Jerusalem

Zohary D, Hopf M (2000) Domestication of plants in the old world: the origin and spread of cultivated plants in West Asia, Europe, and the Nile Valley. Oxford University Press, New York 